\title{
BUSINESS ANTHROPOLOGY, ANOMIE, AND DYSFUNCTION: TRANSCENDING THE TYRANNY OF THE MAJORITY
}

\author{
Alf H. WALle \\ UNIVERSITY OF ALASKA AT FAIRBANKS
}

The impact of economic development upon ethnic and cultural diversity is discussed with reference to the concept of anomie in which socially acceptable goals can no longer be achieved in socially acceptable ways. Specific responses to anomie are explored with reference to the "tyranny of the majority", in which people's needs are denied after being outvoted. Strategies such as the "concurrent majority" can help the ethnic minorities protect their rights and heritage. Business anthropologists have an important role in this regard.

Keywords: anomie, tyranny of the majority, concurrent majority, cultural change, dysfunction

\section{Introduction}

Many business leaders embrace the simplistic view that worldwide cultural uniformity is inevitable. In reality, of course, great diversity exists, and this variation is a positive asset. Nevertheless, rapid social and economic changes (some of them encouraged by business and/or fuelled by the pressures associated with it) challenge and stress the ethnic and minority groups.

Facing such circumstances, social equity and self-determinism is often sought. Opponents of such initiatives, in contrast, advocate some sort of universal standards: this is the popular "global" orientation so influential in business today. Others find this universal/global paradigm to be hurtful and wrongheaded. The discussion here contributes to a dialogue regarding how disagreements such as these can be resolved. 


\section{Change, Stress, and Pain}

Cultural enclaves are often adversely affected by cultural, social, economic, and/or technological changes. Being asked to adhere to alien traditions can be especially painful. In other words, "minorities" (envisioned broadly as those lacking power and control) often suffer due to contact with powerful forces that seek compliance to their standards. Subjected to such conditions, people often exhibit hurtful dysfunction.

Discussing these pressures on an individual basis from within the mainstream world, Appelberg, Romanov, Honkasalo, and Koskenvuo (1996) report that people who experienced a significant conflict at work during the previous 5 years were more likely to be diagnosed with a psychiatric problem than those who did not. Apparently, significant stress in dealings with other people can result in detrimental and hurtful ramifications.

The average person who experiences difficulties at work, however, is still a member of a viable and intact culture or society. Presumably, the cultural and social support available to these individuals continues and, in the process, provides comfort and balance even when these people experience hardships on the job. When away from work, furthermore, such sufferers enjoy a respite from their adverse vocational experiences by participating in the larger community, but even when this comfort is available, there is an increase in mental illness and its pain. This situation promotes dysfunction.

The relative comfort provided by cultural stability can be juxtaposed with the opposite situation where the entire culture, heritage, and traditions of a people are attacked, weakened, rendered passé, or even destroyed. These people are likely to be more vulnerable to adverse psychological responses than those who merely suffer from "on the job" pressures.

For many years, advocates for ethnic groups have understood that change has hurtful potential that need to be proactively addressed. The necessity to do so is particularly important when a people's way of life has been quickly transformed, weakened, or destroyed by some unanticipated, uncontrolled, and/or unmitigated onslaught. The agendas or actions of some "majority" (however defined) are typical catalysts for maladies of this sort.

Consider the case of Ishi, the lone survivor of a California (USA) tribe, who was dubbed the "Last Savage" by the media and became a tourist attraction as well as the subject of anthropological research in the early twentieth century (Kroeber, 1964). Many Native American thinkers point to the treatment of Ishi as a classic example of oppressive exploitation in 
which outsiders first destroyed the man's way of life and then turned him into a commodity for tourists to gawk at. Although such conclusions are understandable, the story and message of Ishi is much more complex than that. It is chronicled by Theodora Krober in her book Ishi: The Last of his Tribe (1964), which explores the relationship between her husband (anthropologist Alfred Louis Kroeber) and Ishi as each comforted the other.

Theodora observes that around the time that Ishi stumbled into the modern world, starving and alone, Kroeber had suffered his own grievous loss. His first wife had died before her time and, as a result, Kroeber was thrown into a profound and disabling depression. Possessing great knowledge of the indigenous people of California, however, Kroeber was asked to help calm this unruly "wild man" who had unexpectedly appeared. Kroeber found a grief-stricken soul who had lost everything, not just a wife. Ishi's world was completely gone and everyone and everything that was important to him was dead. Nothing remained. Ultimately, Kroeber realized that suffering over a lost wife was relatively insignificant when compared to the agony of a victim whose entire social universe had quickly and irreversibly become extinct. In the process of helping Ishi adjust and cope, the grieving widower learned to deal with his own pain. Both men found salvation by helping each other.

The point of these observations is that Kroeber came to recognize the profound suffering people feel when their heritage is stripped away. Although Ishi provides an extreme example of such anguish, this type of cultural and social loss is very common among ethnic groups who are confronted by the mainstream world or other powerful forces beyond their control. The business community needs to recognize this pain as well as the potential for dysfunction that stems from it. Business anthropologists can be more effective by being aware of the ramifications of cultural decline or destruction. Our profession can also develop methods and perspectives that help preserve the cultures that are experiencing economic transitions as well as mitigate the negative aspects of change and loss.

A classic discussion regarding the discomfort triggered by change is presented by G.N. Appell, who observes that a strong and robust cultural heritage can help people cope with the impacts of traumatic change. Appell reminds us that "A society undergoing change...has a right to access its cultural traditions, its language and its social history" (Appell, 1977:14), because these cultural assets can help temper the pain and disorientation caused by what he calls the social separation syndrome, which "involves role conflict and ambiguity, threat to one's self esteem, and an impaired social identity". 
Discussing this social and psychological threat, Appell (1977:14) continues, "Social bereavement arising from social change seems to follow a developmental sequence similar to personal bereavement...There is first a period of denial as numbness accompanied by anxiety, fear, and feelings of threat to one's identity. This is succeeded by a phase of frustrated searching for the lost world or individual, hoping for a reversal and then bitter pining and unrelieved sense of pain...Following this is a period of depression and apathy...Finally there is the phase of reorganization when the bereaved begins to build new plans and assumptions about the world."

Some of the details of Appell's vintage observations might be dated or metaphoric, but the gist of his message continues to resonate clearly. Cultures are powerful coping devices that provide grounding, practical tools, comfort, and a sense of identity. They offer solutions to the problems that people face as well as present suggestions regarding how to think, act, and respond. If these tools are undercut, rendered passé, or destroyed, a void can emerge causing people to lack the ability to live in a socially and psychologically healthy fashion. These perspectives are useful to business anthropologists who seek to help cultural enclaves respond to changes wrought by economic activities.

Although this vulnerability is real, it does not inevitably lead to cultural extinction. In a classic observation, for example, David Maybury-Lewis (1977:58) reminds us that "There is no natural or historic law that militates against small societies. There are only political choices." Thus, business anthropologists need to remember that the demise of ethnic groups is avoidable even if popular paradigms of cultural evolution and extinction reflect the world view (and perhaps the priorities) of many advocates of economic development, change, or conformity.

\section{Anomie: the Disruption of Chang}

Social scientists recognize that change can lead to pain that triggers hurtful dysfunction. In the late nineteenth century, Emil Durkheim, for example, demonstrated how unhappiness and despair that is correlated with social displacements can lead to a growing suicide rate (Durkhiem, 1893). Durkheim explained this relationship with reference to what he called "anomie", which refers to tensions and alienation triggered by significant disruptions or alterations in the daily life that people experience. Durkheim clearly recognized that unmitigated social change can produce dysfunctional, harmful, and counterproductive behavior.

Durkheim envisioned anomie as an inconsistency between (1) the prevailing social standards and/or acceptable behavior, and (2) the realities 
that actually exist. When the inconsistency between the two is great, the rules of society begin to deteriorate or break down, creating a chaotic and unpredictable environment capable of launching alienation, sorrow, a feeling of hopelessness, and hurtful responses.

In the 1940s and 1950s, Robert Merton (1957) expanded Durkheim's concept of anomie, arguing that the norms of society provide individuals with (1) goals to which they should aspire, on the one hand, and (2) conventional methods for achieving these objectives, on the other. Merton understood that over time the social structure (or the socio-economic milieu in which a community exists) may change to such a degree that its members are no longer able to attain sanctioned and honored achievements in the traditionally acceptable manner. Under such conditions, the predisposition for deviant and/or dysfunctional behavior tends to increase.

Social and economic development projects or initiatives involving ethnic groups can easily create conditions that give rise to anomie. The ways in which people respond under these conditions, however, vary with some alternatives being more productive and positive than others. Merton provides a typology of responses to anomie that includes (1) conformity, (2) innovation, (3) ritualization, (4) retreatism, and (5) rebellion (Merton, 1957). They can be described as:

Conformity: A situation in which people continue to embrace the goals of their society and seek to achieve them in traditional socially acceptable ways. Conformers continue to respond in the manner they did before the pressures causing anomie were present. Conformity is a conservative response and it preserves the traditional relationships between people. Conformity, however, can inhibit the ability to adjust to new conditions.

Innovation: A situation where people embrace the goals of the society but attempt to achieve them using new methods that might not be socially acceptable. Mainstream sociologists often characterize these methods as illegal and antisocial. Among ethnic groups, however, innovation might include responses that, while violating traditional norms or expectations, result in productive and moral adaptation. If so, embracing productive, but taboo behaviors as legitimate methods for achieving socially acceptable goals might be a positive response that benefits the society.

Ritualization: A situation where people act according to the norms of the society but lose track of the goals to be achieved. In this case, people begin to act in a rote manner using tradition as a guide with little focus on the costs versus the benefits of doing so. This type of response is not 
strategic and is not likely to be productive. When people follow the old way merely as an end in itself, the ability to respond in a productive and beneficial manner is reduced.

Retreatism: A situation where people reject both the cultural goals and the institutionalized methods for achieving them. Although people might reject the status quo, they do not necessarily embrace any positive or beneficial alternative. The potential for dysfunctional responses, such as alcohol abuse, increases. While under the influence of alcohol or drugs, for example, the victim might be temporarily distracted from the plight faced but will fail to respond in an effective manner.

Rebellion: A situation where people (1) reject both the goals that the society provides and the traditional means of achieving them while (2) simultaneously embracing substitutes that take their place. Under such circumstances, the break with the old ways is profound and complete. Massive changes in thoughts and attitudes take place when the old ways are discarded and new alternatives embraced. This might result in chaos. Different factions might arise in conflict with one another. The situation, created by widespread rebellion, can be particularly painful to those who hold on to tradition and/or fear change.

Anomie, therefore, can spawn a range of responses that are related to how individuals and the community deal with the pressures faced. These alternatives are compared in Table 1 .

In conclusion, the concept of anomie deals with the tensions caused by social change. Business anthropologists can use this model to better understand the variety of ways in which people cope with the disruptive pressures facing them. In recent decades, various refinements, such as strain theory, have been developed that focus upon how and why people respond to stress. Although such theories are often used to depict criminal and antisocial behavior and its causes, the same approach can be used to examine any significant change in behavior, good or bad, that people exhibit. On many occasions, reactions to anomie are disruptive and painful. Other responses may be positive. By understanding this range of reactions, business anthropologists, strategists, and policy makers can recognize significant side effects of cultural contact and change as well as realize how to most effectively deal with them. 
Table 1: Responses to Anomie

\begin{tabular}{|c|c|c|}
\hline RESPONSE & DESCRIPTION & ANALYSIS \\
\hline Conformity & $\begin{array}{l}\text { The traditions of the } \\
\text { culture are preserved. } \\
\text { People and the community } \\
\text { continue to be motivated } \\
\text { and act as in the past. }\end{array}$ & $\begin{array}{l}\text { The community along with } \\
\text { its culture is stable, but } \\
\text { strategically responding to } \\
\text { circumstances is minimal. } \\
\text { Little positive adaptation. }\end{array}$ \\
\hline Innovation & $\begin{array}{l}\text { Although the goals of the } \\
\text { society remain intact, } \\
\text { people embrace new } \\
\text { methods of achieving them. }\end{array}$ & $\begin{array}{l}\text { Although the goals of the } \\
\text { community are maintained, } \\
\text { the means of achieving } \\
\text { them evolve to reflect the } \\
\text { new circumstances. }\end{array}$ \\
\hline Ritualization & $\begin{array}{l}\text { People continue to act } \\
\text { according to the old } \\
\text { conventions of behavior, } \\
\text { although doing so has little } \\
\text { ad hoc value. }\end{array}$ & $\begin{array}{l}\text { Although the ways of the } \\
\text { past continue to be } \\
\text { embraced, strategically } \\
\text { responding to the new } \\
\text { conditions is insignificant. }\end{array}$ \\
\hline Retreatism & $\begin{array}{l}\text { People withdraw and } \\
\text { abandon the old ways, but } \\
\text { do not embrace a new } \\
\text { alternative. }\end{array}$ & $\begin{array}{l}\text { Psychologically, people } \\
\text { are cut off from their } \\
\text { heritage. Dysfunctional } \\
\text { responses are likely. }\end{array}$ \\
\hline Rebellion & $\begin{array}{l}\text { New goals and new codes } \\
\text { of behavior are embraced. }\end{array}$ & $\begin{array}{l}\text { People replace both the } \\
\text { traditional goals and the } \\
\text { strategies used to achieve } \\
\text { them. }\end{array}$ \\
\hline \multicolumn{3}{|c|}{$\begin{array}{l}\text { DISCUSSION } \\
\text { When people experience change and anomie, a number of different } \\
\text { responses are possible. By being aware of this variety, business } \\
\text { anthropologists can more effectively understand the impacts and } \\
\text { implications of specific examples of economic development as well as } \\
\text { how to effectively deal with them. }\end{array}$} \\
\hline
\end{tabular}

\section{Representative Examples of Dysfunction}

On some occasions, unmitigated change and stress can cause people to exhibit rather bizarre beliefs and actions. Three such examples are the Ghost Dance (Mooney, 1896; Kehoe, 1989), the cargo cult (Harris, 1974; Inglis, 1957; Worsley, 1957), and the Cultural Revolution in China. Each is a case study of the problems that can arise when cultures adapt. 
The Ghost Dance was an influential late nineteenth-century religious movement among Native Americans. Its most prominent leader was a visionary named Wovoka who intertwined the aspects of local traditions with a new religion. Some of Wovoka's recommendations asked the people to live in a more productive, moral, and harmonious manner. These suggestions were positive and productive aspects of the movement.

Others beliefs, however, were counterproductive and hurtful. Wovoka, for example, taught that if a certain dance was properly performed, the dead ancestors would come back to life, herds of buffalo would return, the white intruders would go away, and the old way of life would be restored. None of these projections, unfortunately, reflected reality. Acting according to them proved to be tragically counterproductive.

Some devotees were even convinced that if they wore "ghost shirts", they could not be killed by the guns of the white man and, therefore, victory was assured. The emerging Ghost Dance and the hope it provided appealed to many indigenous people who had suffered grievously due to reservation life, sickness, cultural decline, and governmental policies that sought to undercut the local Native American heritage. Sadly, the Ghost Dance activities led to the massacre at Wounded Knee, the last major bloodbath of the Indian Wars.

Viewed from the perspective of anomie, the Ghost Dance can be viewed as an example of conformity in which the traditions of the culture were largely preserved and embraced, albeit in an unproductive manner. People were encouraged to look to the past, ignore the reality, reject the new order of things, and act accordingly. Unfortunately, by doing so, the actual circumstances being faced were not addressed in any meaningful manner. The result was disastrous.

The cargo cult, usually associated with Melanesia, involved people whose lives were hurtfully transformed and disrupted by social and economic change associated with outside businesses during the early twentieth century. Apparently, these reactions to the circumstances were attempts by indigenous people to reassert control over their lives in a world that was being irrevocably changed in ways that undermined the old economic system and way of life, leaving the local people in a precarious and bewildering situation.

The responses to these hurtful circumstances are well known. When the outside businesses began to gain a foothold in Melanesia, members of the indigenous community noticed that these powerful outsiders built airports and harbors and then waited for airplanes and ships to arrive with great wealth. Apparently, the local people, becoming desperate and jealous, wanted their share of the cargo. One ploy they used was to build 
phony airports in the misguided belief that by doing so they could magically attract their own supernatural airplanes and gain affluence as a result.

Although such responses are typically associated with some charismatic leader, a common explanation is that these cargo cults were responses to sorrow, fear, and anxiety caused by rapid and uncontrolled change. Although such strategies might be associated with ignorance and superstition coupled with a lack of familiarity with modern economics and technology, the most important catalysts seem to have been desperation, hopelessness, and disappointment.

Viewed from the perspective of anomie, the cargo cults appear as innovative and/or rebellious responses to anomie. Devotees of the cult, for example, embraced new ways to achieve goals (luring cargo carrying planes by building bogus airports) even though other aspects of their society probably remained intact. This behavior might also be reflective of rebellion in which new goals (a desire for western goods) were accompanied with new economic strategies (luring cargo planes). In any event, a major adjustment (although counterproductive) took place. It was precipitated by profound tensions in the culture and economy caused by rapid outside contact.

Such reactions do not just occur among small-scale cultures made up of undereducated people. Consider the Cultural Revolution in China during the 1960s and 1970s when militants, encouraged by Chairman Mao, rejected and attempted to destroy the rich cultural heritage of the Orient. This movement (Lee, 1978; King, 2010) sought to eliminate the remnants of Western business practices as well as the aspects of Chinese civilization that were considered to be old fashioned and holding China back from progress. This reaction appears to have been triggered by the social and economic troubles that China was experiencing during that era.

As a political movement, various purges eliminated the leaders who were considered to be too connected with the bourgeois. Culturally, many Chinese, especially the young, lashed out against China's rich heritage. Millions of people were harassed, shamed, and punished because they were identified with the Chinese civilization or its traditions and knowledge. Intellectuals, teachers, writers, and cultural leaders found themselves under attack.

Innumerable relics from China's impressive historic legacy were destroyed or mutilated. Thus, when I visited the tomb of Confucius a few years ago, I discovered that his grave marker had been badly damaged during the excesses of that era. Today, of course, repairs have been made and the Chinese people (and the rest of the world) hold Confucius in the 
highest of esteem. During that period, however, anyone who was identified with the past, even world famous philosophers, became vulnerable.

Archaeological remains, archives, art works, and artifacts were destroyed in a massive wave of devastation. The Cultural Revolution is thus an example of people strongly rejecting their culture and all it stood for. According to the theory of anomie, this can be viewed as an example of how people reacted when they could not achieve socially acceptable goals in a socially acceptable manner. It took the form of rebellion in which the old ways were rejected and replaced with alternatives that were distinctive and dissimilar from the past. Although this movement was the work of overenthusiastic zealots (and not actually officially condoned by the government), the destruction was profound and seemed to be a spontaneous reaction, similar in some ways to the Ghost Dance and the cargo cults. All three were encouraged by charismatic leaders but rooted in a feeling of hopelessness and a grassroots demand for profound change triggered by troubled times.

The Chinese Cultural Revolution is now recognized as a disaster by the Chinese as well as the rest of the world. Today in the Middle East, unfortunately, some forces have begun to attack the rich cultural legacy of the region by destroying archaeological ruins, monuments, and the artistic achievements of the past. Although these events are unique and distinctive in some ways, they also seem to be emotional responses triggered by the heat of the moment and not careful thought. Like the Chinese Cultural Revolution, they are tragic examples of the wanton destruction of an irreplaceable heritage. Business anthropologists need to be aware of the possibility that reactions and responses of this type can occur in many different settings.

These examples demonstrate that a strong potential exists for people to make poor decisions when they are faced with hurtful disruptions in their way of life. The theory of anomie can be used to model these changes. With this in mind, the Ghost Dance, the cargo cult, and the Cultural Revolution are compared in Table 2.

The Ghost Dance, the cargo cult, and the Chinese Cultural Revolution point to the damaging and ineffective methods of addressing social and economic change. They demonstrate that when people are not prepared for the conditions they face, dysfunction is likely to occur. The opposite, however, is also true: some cultures and the people within them respond to the pressures faced in positive and constructive ways while simultaneously maintaining their unique cultural character and distinctiveness. The Iroquois Indians of New York State (USA) and Ontario (Canada) and the Yup'ik of Alaska (USA) are such examples. 
Table 2: Patterns of Dysfunctional Response

\begin{tabular}{|c|c|c|c|}
\hline ISSUE & GHOST DANCE & CARGO CULT & $\begin{array}{l}\text { CULTURAL } \\
\text { REVOLUTION }\end{array}$ \\
\hline Trigger & $\begin{array}{l}\text { Cultural Stress. } \\
\text { Economic } \\
\text { reversals. }\end{array}$ & $\begin{array}{l}\text { Cultural Stress. } \\
\text { Economic } \\
\text { reversals. }\end{array}$ & $\begin{array}{l}\text { Cultural stress. } \\
\text { Economic } \\
\text { reversals. }\end{array}$ \\
\hline Response & $\begin{array}{l}\text { A belief in a } \\
\text { magical return of } \\
\text { ancestors and the } \\
\text { old ways, and } \\
\text { personal } \\
\text { invincibility. }\end{array}$ & $\begin{array}{l}\text { A misguided } \\
\text { copying of the } \\
\text { techniques used by } \\
\text { the outsiders who } \\
\text { threatened the } \\
\text { traditional way of } \\
\text { life. }\end{array}$ & $\begin{array}{l}\text { Widespread } \\
\text { disrespect and } \\
\text { rejection of } \\
\text { cultural traditions } \\
\text { long held by the } \\
\text { Chinese people } \\
\text { and their culture. }\end{array}$ \\
\hline Impact & $\begin{array}{l}\text { Suicidal behavior. } \\
\text { Reliance upon } \\
\text { magic. }\end{array}$ & $\begin{array}{l}\text { Counterproductive } \\
\text { economic } \\
\text { strategies. }\end{array}$ & $\begin{array}{l}\text { Cultural } \\
\text { destruction on a } \\
\text { massive scale. }\end{array}$ \\
\hline \multicolumn{4}{|c|}{$\begin{array}{l}\text { DISCUSSION } \\
\text { The Ghost Dance, the cargo cult, and the Cultural Revolution represent } \\
\text { hurtful and unproductive responses to change, stress, and anxiety. } \\
\text { Business anthropologists need to be aware of such potential reactions in } \\
\text { order to envision more strategies. }\end{array}$} \\
\hline
\end{tabular}

\section{Positive Adaptations}

The Iroquois of New York State (USA) and the Province of Ontario (Canada) are impressive in many ways. In the eighteenth century, they successfully manipulated the colonial forces of Britain and France, reaping significant benefits in the process. During the French and Indian War (1754-1763), known as the Seven Years' War in Europe, the Iroquois strategically controlled the situation and enjoyed prosperity as a result. Once the French had been totally defeated and driven from North America, however, the Iroquois were "no longer able to play off the British and French against each other and [found themselves] surrounded by a circle of British forts" (Wallace, 1970:442). Because an alliance with the Iroquois was no longer strategically important, British generosity dwindled and economic suffering crept in.

When the Revolutionary War between Britain and their North American colonists began, the Iroquois became embroiled, once again, in a conflict that was larger than their world. Realizing that the British valued the region merely for trading purposes while victorious colonialists would 
probably be tempted to migrate into Iroquois territory, most Iroquois sided with Britain. The decision was costly:

[During the war, the Iroquois homeland] was devastated by the John Sullivan [United States military commander] expedition in 1778, which in a three-pronged offensive managed to burn the houses and the crops in almost every major Iroquois town. Many of the women and children, and the surviving warriors, took refuge at Fort Niagara with the British, who housed them in a refugee camp, inadequately clothed, inadequately fed, inadequately sheltered, and swept by disease. By the end of the war, despite their military successes, the Iroquois population had been cut approximately in half. (Wallace, 1970:443)

After the war, the victorious United States, remembering that the Iroquois had been their enemy, showed them few favors. And, as the Iroquois had feared, white settlers were attracted to the area. By the turn of the nineteenth century, the Iroquois were beaten in war, decimated by diseases brought by the Whites, and besieged by new economic rivals. The results of this unenviable situation included infighting, personal resignation, despair, and retreat. As is often the case under such circumstances, dysfunctional behaviour (including alcoholism) became rampant.

Anthropologist Anthony Wallace, an Iroquois specialist, points to the widespread dysfunction that arose, including violence, uncontrolled weeping and pining, fear of peers (as evidenced by accusations of witchcraft), social disunity, and widespread alcoholism. Clinical depression was commonplace and Wallace (1970:196-201) observes that when people were sober, they were likely to be suicidal. With its culture and people in total disarray, the Iroquois, as a viable culture, appeared to be headed towards extinction.

Within this milieu of cultural decline, Handsome Lake, a once-respected indigenous leader, had fallen into hopeless alcoholism and his productive life appeared to be over. By the spring of 1799 , he was "bedridden, reputedly...as a consequence of prolonged [alcoholism]" (Wallace, 1978:445).

In June of that year, "Handsome Lake collapsed [and] appeared to have died, but actually he was in a trance state and was experiencing the first of a series of visions in which messengers of the Creator instructed him in his own and his people's religious obligations" (Wallace, 1978:445). After recuperating, Handsome Lake dedicated his life to sobriety and to the restoration of Iroquois culture and society.

Handsome Lake encouraged his people to embrace their cultural traditions in innovative ways. The late eighteenth and early nineteenth 
centuries had devastated the Iroquois, throwing their culture into a state of complete disarray. Economically, the Iroquois could not effectively compete with the new settlers who entered the regions. Although embracing and championing the Iroquois culture, Handsome Lake also recognized that the Iroquois society needed to adjust to the emerging economic realities in order to be revitalized.

Iroquois men, for example, focused upon hunting and warfare, viewing farming as an unmanly and shameful profession that was left to women. When the white settlers migrated to the Iroquois territory, however, new methods of farming (that included men performing their share of the work) proved to be more efficient and productive. The success of these outsiders further undercut the Iroquois economy. In these circumstances, Handsome Lake encouraged the Iroquois men to take up farming and he urged them to perceive agriculture as a legitimate profession, not a source of shame or embarrassment. This change of attitude helped the Iroquois to rebound economically.

The response suggested by Handsome Lake is clearly an example of what Robert Merton describes as an innovative response to anomie in which the goals of the society remain intact although people are provided with new methods for achieving them. While Merton often associated innovation with harmful and hurtful substitutes such as illegal activities, in this case innovation took the form of a productive and legitimate rethinking of traditional sex roles. It allowed the Iroquois to adjust to the emerging social and economic circumstances.

Handsome Lake, furthermore, forcefully denounced the disruptive and dysfunctional responses exhibited by his people. Drinking alcoholic beverages, in particular, was banned, along with promiscuous sexual behavior, the practice of witchcraft, and other troublesome habits that were undercutting the society and its people. Handsome Lake went on to insist that people acknowledge their past errors and refrain from similar misdeeds in the future.

From the perspective of anomie, Handsome Lake seems to have intuitively understood that many people had fallen into responses that resembled retreatism; they had abandoned the old ways but had not replaced them with any positive alternatives. He demanded that people find a meaningful focus and begin to combat social and individual degeneration.

Largely through Handsome Lake's example and message, the Iroquois people reversed their downward spiral of decline and re-emerged as a vital and viable culture. They continue as a powerful force today. This example reminds business anthropologists that ethnic groups can adapt to changing 
circumstances by maintaining their traditions while transforming them in productive and strategic ways. Cultures are powerful forces and as Appell indicated, they often provide invaluable tools for both physical survival and psychological health. In addition, they are flexible and capable of innovation and change.

Approximately 175 years after Handsome Lake's achievements, Alaskan native Harold Napoleon provided another example of cultural renewal. Napoleon's Yuuyaraq: The Way of Being Human (1996) examines his indigenous people (the Yup'ik of southwestern Alaska, USA), focusing upon the trauma and stress caused by contact with the outside world during the twentieth century. Napoleon chronicles the plight of a downtrodden and bewildered people who fell into disarray and dysfunction but ultimately rebounded with healing and renewal.

Instead of being a scholar or a professional researcher, Napoleon is an insightful layman who recovered from a personal bout with alcoholism. Writing on a subjective and intuitive level, Napoleon discusses the traumatic events that undercut the Yup'ik society (as well as the positive steps to be taken to ensure its renewal). Revealingly, these observations and recommendations independently duplicate the example and suggestions of Handsome Lake.

While not excusing or discounting his lapses and personal responsibilities, Napoleon focuses upon the destructive power of uncontrolled social and economic change and the alienation and disruption it produces. He argues that social and individual dysfunction can best be overcome through cultural revitalization.

Napoleon points to the irony that profound decline among the Yup'ik was correlated with economic progress and physical wellbeing. The people had warm clothes, comfortable homes, and enough to eat. Famines were a thing of the past. Viewed from the materialistic perspective, life was good. Nonetheless, the suffering was profound, alcoholism was rampant, and the suicide rate rose to epidemic proportions. Business anthropologists can use this example to remember that conventional measures of quality of life, such as the availability of material possessions, do not always indicate positive circumstances.

Napoleon explains these responses as the fruit of cultural destruction. He records that in the early twentieth century, disease had killed many of the elders who carried the traditions of the Yup'ik culture. As a result, the survivors were denied their heritage and thus they floundered emotionally. Economically, moreover, the traditional subsistence lifestyle was rendered passé. This situation, of course, is largely similar to what Handsome Lake's Iroquois faced in the late eighteenth and early nineteenth centuries. 
The responses, furthermore, were almost identical: dysfunctional behavior, mass suicide, despair, and passive resignation. Business anthropologists need to remember this potential and what triggers it.

The solutions/suggestions by the Iroquois and the Yup'ik, furthermore, are almost identical even though there is no evidence that Napoleon was aware of his predecessors. In both cases, cultural renewal and embracing of the local heritage and traditions were urged. The rationale underlying these tactics is the belief that by nurturing and rebuilding the culture and its traditions, the people can heal from a painful past and a new and positive chapter in their culture can begin.

Napoleon uses the theory of Post-Traumatic Stress Disorder as a metaphor for portraying the painful process of stress, alienation, and dysfunction that long plagued his culture and people. Post-Traumatic Stress Disorder, of course, is a condition in which people develop dysfunctional patterns of response as a result of being exposed to danger, fear, stress, and so forth. Speaking with reference to this disorder, Napoleon argues that the rapidly changing social and economic conditions caused unmitigated stress that, in turn, triggered dysfunctional responses and behaviors that almost destroyed the Yup'ik. This ongoing process proved to be a vicious circle because as the culture became weaker, it became less able to help people cope, leading to even more profound problems.

Discussed in terms of anomie, a pattern of retreatism emerged in which people abandoned their old ways but did not replace them with new and powerful alternatives.

A key strength in Napoleon's account is that he is not a professional social scientist or psychologist. Indeed, his status as an insightful layman who is a member of his community, gives his work added credibility. This analysis has special value because it independently verifies and reinforces the findings of researches such as of Merton and Appell while simultaneously paralleling the example of Handsome Lake. Parallels between these two examples are presented in Table 3.

Business anthropologists can be more effective if they keep these positive examples in mind. Social change, economic development, and business intervention trigger change. On many occasions, hurtful reactions are the result. Positive alternatives, however, are possible. Business anthropologists have a role in helping ensure that transitions caused by economic activities are positive, sensitive, as well as culturally and psychologically beneficial.

The fact that pain and alienation may exist, of course, does not mean that outsiders should force people to preserve and live according to their 
traditions. Self-determinism at a local level should prevail. People, however, need to understand the full implications of their actions.

In this regard, Ormund Loomis (1983:29) has observed, "Proposing... efforts to stem...inevitable change would be pointless. Further, in a free society, even expecting [organizations or] the government to slow...[inevitable] progress would be wrong... It is possible, however, to temper change so that it proceeds in accordance with the will of the people, and not in response to the pressures of faddish trends or insensitive public or private projects."

Table 3: Positive Adaptation

\begin{tabular}{|c|c|c|}
\hline EXAMPLE & $\begin{array}{l}\text { HURTFUL } \\
\text { PRESSURES }\end{array}$ & $\begin{array}{l}\text { POSITIVE } \\
\text { RESPONSES }\end{array}$ \\
\hline $\begin{array}{l}\text { Handsome } \\
\text { Lake }\end{array}$ & $\begin{array}{l}\text { Due to the changing } \\
\text { political and economic } \\
\text { conditions, the Iroquois } \\
\text { suffered. The resulting } \\
\text { sorrow triggered disabling } \\
\text { dysfunctional behavior. }\end{array}$ & $\begin{array}{l}\text { Handsome Lake called for } \\
\text { the people to preserve } \\
\text { their heritage while } \\
\text { adapting to the changing } \\
\text { social and economic } \\
\text { conditions. The decline of } \\
\text { the Iroquois was } \\
\text { overcome. }\end{array}$ \\
\hline $\begin{array}{l}\text { Harold } \\
\text { Napoleon }\end{array}$ & $\begin{array}{l}\text { Due to the new conditions } \\
\text { caused by disease and the } \\
\text { intervention of outsiders, } \\
\text { the Yup'ik faced a crisis } \\
\text { leading to } \\
\text { counterproductive } \\
\text { responses and personal } \\
\text { dysfunction. }\end{array}$ & $\begin{array}{l}\text { Harold Napoleon noted } \\
\text { that the people suffered } \\
\text { because they lost touch } \\
\text { with their heritage and } \\
\text { traditions. He suggested } \\
\text { reconnecting with their } \\
\text { cultural heritage in order } \\
\text { to cope more effectively. }\end{array}$ \\
\hline \multicolumn{3}{|c|}{$\begin{array}{l}\text { DISCUSSION } \\
\text { Although some responses to anomie (such as the Ghost Dance, the cargo } \\
\text { cults, and the Cultural Revolution) are hurtful and counterproductive, } \\
\text { alternatives exist. The examples offered by Handsome Lake and Harold } \\
\text { Napoleon demonstrate this potential. Business anthropologists can benefit } \\
\text { by being aware of such examples. }\end{array}$} \\
\hline
\end{tabular}

Business anthropologists need to remember that the cultural heritage and traditions of a people can be a source of great strength and comfort. Also, they should not forget that transformations and regulations mandated by outsiders can undercut a culture in hurtful ways leading to stress, 
psychological discomfort, and dysfunction (Salzman, 2001; Walle, 2004). Care needs to be taken to minimize this kind of negative and hurtful response. The examples of the Iroquois and the Yup'ik prove that positive and constructive responses are possible.

Many methods for strengthening the cultures of ethnic minorities can be proposed. One example is the concept of what has been called the "concurrent majority", a political construct that was developed in the United States during the first half of the nineteenth century to protect the rights of the minorities that are threatened by the will of the majority. This strategy was a reaction to what has been called the "tyranny of the majority".

\section{The Tyranny of the Majority}

Empowering minorities (such as ethnic groups) to live as they see fit is profoundly important. The discussions of the Iroquois and the Yup'ik dramatize this reality. Having a foot both in cultural diversity and economic activity, business anthropologists have a special role to play in helping the local people and the outside partners operate in ways that are mutually beneficial.

As also discussed, significant obstacles often prevent people from following their preferred ways of life. Denying people the right to self-determinism is often labeled the "tyranny of the majority". The term "majority" can be used to refer to being outvoted by a numerical superiority (such as in an election). It can also refer to domination that results when others control a "majority" of some kind of power, such as economic or political clout, that is used as leverage.

The phrase "tyranny of the majority" goes back to the eighteenth century and was used by American political theorist John Adams in 1788. In the early nineteenth century, it was employed by Alexis de Tocqueville in his book Democracy in America (1835). De Tocqueville, of course, was a liberal who favored democracy but was leery that unbridled majority rule could turn ugly, as it did during the French Revolution. The phrase and the concept it represents gained additional international attention in John Stuart Mill's On Liberty (1859).

When significant social or economic initiatives take place, local people and communities often fear that the resulting changes will be detrimental. A key question that can arise is, "To what degree does a raw majority have the right to control and veto the way of life and the economic activities of distinctive and established minorities?" Put another way, "Should minorities be able to practice self-determinism even when doing so violates the 
principles that are held by the majority?" Many advocates for liberty and equity believe the answer to this question should be, "Yes".

These are complex issues of interest to business anthropologists. For justifiable and laudable reasons, the raw majority (and the countries in which they reside) want to establish uniform standards that provide guidance in their territory (or even globally, as argued by proponents of universal human rights). Majority rule can help create these sought after standards. On the other hand, if the dictates of the majority are strictly followed, the legitimate choices of the minorities might be curtailed.

In the United States of America, this dichotomy has led to controversy and inconsistency. On some occasions, the United States demands that its indigenous people honor the demands of the majority. Thus, indigenous tribal courts are allowed to operate, but only if the defendants are guaranteed all the rights granted by the United States (such as the ability to personally confront accusers and/or those who are witnesses against them). Thus, the rights of indigenous minorities, although acknowledged, are tempered by policies that are established by the majority even though they might conflict with the local traditions.

In other circumstances, the will of minorities prevails over the preferences of the majority. Indigenous people of the United States, for example, are allowed to operate casinos and games of chance in states where the majority of the population has outlawed gambling. In such cases, the democratically established decrees of the majority are overruled by the will of the minority. (The complex rationales for these conflicting policies are not discussed here because they are distinctly American. The point being made is that ad hoc variation and inconsistency exist.)

The Kurdish people of the Middle East present another example of majority versus minority rights in conflict. The region of Kurdistan is a vast area in which the Kurds are in majority. This region, however, is parceled out to a number of nations including Turkey, Syria, Iraq, and Iran. In each of these sovereign countries, the Kurds are a minority. Many Kurds complain that their inherent rights and needs are denied because of their minority status. In some countries, attempts are made to provide the Kurdish people with a degree of autonomy and home rule that takes their distinctiveness into account while simultaneously integrating these regions and their people into the countries where they reside. Even when such concessions are present, many Kurds believe that the only legitimate solution is for the various parts of Kurdistan to be united to form a new country. This paper has no suggestions regarding how to resolve the problems and does not take sides. The compelling arguments of both sides are recognized. 
By looking at these representative examples from North America and the Middle East, the business anthropologists are reminded of the potential problems and inequities associated with relying upon simple majority rule. These tensions need to be resolved. Business anthropologists have a role in doing so.

\section{A Sample Method of Response: the Concurrent Majority}

Ethnic groups have an unexpected friend in the nineteenth century American political theorist John C. Calhoun. Many will find this alliance to be ironic because Calhoun was a stalwart defender of a social and cultural elite that exploited racial and/or ethnic minorities (such as the nineteenth century slave population of the United States).

In this regard, liberal American historian Richard Hofstadter (1948) observes "Not in the slightest was [Calhoun] concerned with minority rights, as they are chiefly of interest to the modern liberal mind - the rights of dissenters to express unorthodox opinions, of the individual conscience against the State, least of all of ethnic minorities." This point is well taken; Calhoun was an apologist who supported slavery and the privileged classes that benefited from it.

In spite of championing an elite gentry that gained fortunes using slave labor, Calhoun grappled with how to protect the rights of the minorities even when outvoted. Although most progressive people today have little sympathy for the "minorities" that Calhoun defended, his logic and thinking, nevertheless, provide generic tactics that can be used to shield any group against the tyranny of the majority. The particular theory that Calhoun developed in this regard is usually called the concurrent majority. It asserts that factions have a right to protect their interests even if outnumbered.

Calhoun's thinking arose in the early nineteenth century when strong tensions existed in the United States between the industrialized North and the agrarian South. The existence of slavery was a key issue, but not the only one (as demonstrated by the arguments over tariffs which seemingly benefited the North at the expense of the South). Calhoun's fear that the minority might be downtrodden by the majority was not unreasonable, and he had repeatedly seen the federal government unlawfully do so.

On March 3, 1832, for example, the United States Supreme Court made a final decision on the case of "Worcester vs. Georgia", which affirmed that the state (which reflects the will of the local majority) had no authority to meddle in the affairs of the American Indians (a minority) who resided in its territory. The case was brought to the Supreme Court by 
an individual who had been detained for breaking a Georgia law that interfered with the rights of the indigenous people to have unregulated contact with the whites.

The United States Supreme Court declared that these laws enacted by Georgia were null and void. However, Andrew Jackson, the then president of the United States, disagreed and took no action. He is reputed to have said "[Chief] Justice Marshal has made his decision, now let's see him enforce it." Since the court had no control over the military, Georgia was not forced to comply. In other words, the administration of the United States (voted into office by a white majority) denied a minority, composed of indigenous people, their legitimate rights in conscious disregard for the law.

Later in the same year, Calhoun and his state of South Carolina rebelled against President Jackson in what is called the Nullification Crisis. "Nullification" is the long-standing principle that if a federal law is illegal, the states may ignore it. At the end of the eighteenth century, the nullification argument had been employed by Thomas Jefferson and James Madison in their opposition of the Alien and Sedition Acts (as articulated in Thomas Jefferson's Kentucky Resolution and James Madison's Virginia Resolution). As a result of such precedence, South Carolina was on familiar ground when it sought relief by cancelling what it felt were illegitimate federal laws. On November 24, 1832, South Carolina passed a law nullifying the tariff within its territory and threatened to secede from the United States. President Jackson stood firm, declared that such action was treason, and threatened military intervention. Eventually, a compromise was reached and the immediate crisis subsided. The underlying belief in nullification, however, remained among the Southern states, emerged as its rallying cry, and prepared the nation for Civil War.

The American Indian Removal Act of 1830, and the forced migrations of Eastern Indians to Oklahoma that it mandated, is an even more blatant example of minority rights being denied by the federal government. Jackson's brutal "ethnic cleansing", known as the Trail of Tears, is one of the greatest injustices in American history. These actions were illegal, shameful, and a flagrant denial of the legitimate rights of a minority. Without doubt, Calhoun was well aware of these examples of the tyranny of the majority.

This was the situation when Calhoun sought strategies for protecting the rights of the minorities who were threatened by majority rule. In general, the term concurrent majority refers to the methods which help an outvoted minority (however defined) to block the initiatives and desires of a majority. As might be expected, such remedies are popular among 
subgroups that feel that, otherwise, they might not be treated with parity and equity.

As noted above, in Calhoun's era, the agrarian cotton planters of the south-eastern United States were outnumbered by the more populated Northern industrialists. In such an environment, Calhoun feared that the Northern majority would unjustly shift laws and economic policies (such as tariffs) to their advantage at the expense of the South. To avoid this possibility, Calhoun insisted that the minorities must possess an ability to maintain their way of life, even when the majority is hostile to it. This basic reasoning continues to be a strong justification for the rights of the minorities, such as ethnic groups. On many occasions, for example, indigenous peoples, such as the Maya of Belize, assert their traditional rights in ways that overtly contradict the will of the majority. They justify doing so by arguing that protecting these rights is key to their survival as a people. They have found support and success when doing so.

Also consider, for example, the Crimean Tatars (Shevel, 2014; Kinstler, 2014; Balson, 2015), an Islamic people, primarily Sunni, who are of Turkish descent. These Tatars have been indigenous to Crimea (an area bridging the Middle East and Central Asia) for hundreds of years - they have a better claim to indigenous status in the area than anyone else.

In the late eighteenth century, Russia defeated the Turkish Empire and took over Crimea. This political shakeup was followed by a mass migration of ethnic Russians into Crimea, making the Tatars a minority in their own land. During World War 2, the Tatars were accused of collaborating with the Germans against Russia and a mass exile resulted. Today, the remnants of this indigenous group constitute only about 15 per cent of the total population.

When Crimea was a part of Ukraine, the Tatars were granted a significant degree of autonomy. Currently, of course, Russia once again controls Crimea and what the future holds for these people is uncertain. Nonetheless, a Tatar leader, Refut Chubarov, has called for an autonomous Tatar region to be established.

Although minorities such as the Maya and the Tatars are very different from the plantation owners who Calhoun defended, the situation they face is largely the same. They all oppose the eroding of the freedom to practice and enjoy their way of life. Calhoun developed the theory of concurrent majority as a defense against the tyranny of the majority, and his logic is as strong today as when it was written in the early nineteenth century. Calhoun's writing, furthermore, is consistent with well-respected political theorists, including liberals such as John Stuart Mill who wrote the celebrated On Liberty (1859). 
When decisions are made purely with reference to majority rule, subgroups can emerge as losers in an inequitable power-grab that favors the numerical majority at the expense of minorities. Calhoun sought to control the tyranny of the majority using methods that protected the minority's rights. In this regard, Calhoun (1851:271-2) rhetorically asks, "How can those who are invested with the powers of government be prevented from employing them as the means of aggrandizing themselves instead of using them to protect and preserve society?" Because of this potential misuse of power, Calhoun argued that the minorities must possess the ability to prevent their rights from being annulled and their legitimate wishes and priorities from being ignored.

Providing these protections can be justified by complaining that without them the will of the majority can be forced upon the minorities in hurtful, burdensome, and unfair ways. This potential is especially strong and oppressive if the minority is significantly distinct from the dominant majority (as is the case with many ethnic groups).

Perhaps in a small and homogeneous community, simple majority rule might function effectively and equitably. However, as the population rises and divisions and differences between segments of the population expand, this ability is reduced. Recognizing this reality, Calhoun (1851:273) observes "the more extensive and populous the country, the more diversified the condition and pursuits of its population; and the richer, more luxurious, and dissimilar the people, the more difficult it is to equalize the action of the government".

Under these conditions, Calhoun (1851:273) concludes that it becomes "more easy for one portion of the community to pervert its powers to oppress and plunder the other". This, of course, is exactly the complaint that is made by many ethnic groups whose lands are dominated by forces that attempt to transform or eliminate the minorities in ways that accommodate the powerful or the majority.

Calhoun's basic point is that the mere will of a majority does not give it the right to destroy the way of life of a minority. Ethnic groups can use Calhoun's theory of concurrent majority to affirm and justify those rights that pure majority rule can easily undermine. Calhoun, furthermore, recognizes that the greater the difference between people, the more likely that the majority actions might prove inequitable to the minorities. Under these circumstances, methods for transcending raw "majority rule" are likely to be needed. 


\section{Discussion}

This paper is not presumptuous enough to assume that an example from the nineteenth century United States can be universally applied by business anthropologists. The use of this specific example merely illustrates that minorities, including ethnic groups, need to embrace their distinctiveness, on the one hand, while recognizing the inevitable reality of change and its challenges, on the other.

As David Maybury-Lewis (1977) indicates, cultures are not necessarily destroyed by contact with the outside world and the pressures of change. If given a chance, most people have a profound ability to adapt. Variation and diversity, furthermore, can be strong and invaluable assets.

Change and the rivalries between people, however, often take a toll. This can be especially true if rapid and unmitigated transformations are forced by outside pressures. Under many circumstances, people find themselves unable to achieve socially acceptable goals in socially acceptable ways. This situation can lead to anomie coupled with the estrangement and bewilderment it often causes.

All too often, the responses to anomie are hurtful and dysfunctional. This is what we saw in the examples of the Ghost Dance, the cargo cults, and the Cultural Revolution. However, positive examples such as those associated with Handsome Lake and Harold Napoleon can also be found. These latter examples demonstrate how cultures can adapt and prosper while maintaining their distinctiveness and essence. Cultural preservation can be combined with an appropriate adaptation to new circumstances.

As was argued above, in order for individual people to avoid pain, suffering, and dysfunction, their cultural heritage needs to remain strong and vital. As a result of this reality, these traditions and heritages also need to be nurtured and protected.

A threat that often needs to be overcome when people face new realities is the "tyranny of the majority", in which powerful outside forces (including business partners) mandate that people adjust in ways that reflect their priorities. Under such conditions, self-determinism and the process of fostering equitable and orderly cultural transformation can be undercut.

Minorities (measured either demographically or with reference to power structures) need methods to resist inappropriate manipulation. Business anthropologists can benefit from being aware of these options and the tradeoffs involved when exercising them. Especially when smaller or weaker cultural enclaves are distinctive and/or their situations are different from those who dominate, basic human rights and the 
self-determinism of minorities might become vulnerable. Under these conditions, small ethnic or cultural enclaves may need additional protections. The method of the concurrent majority is one illustrative example of how these goals can be accomplished.

These are issues that impact business anthropology and the cultural enclaves it deals with. Many small minorities must grapple with social and economic change. They need the advice that business anthropologists can provide. These people, furthermore, have human and cultural rights and needs to protect. By working with these people and their economic partners, business anthropology can emerge as a powerful and much-needed force. By doing so, business anthropology can help foster equitable and mutually beneficial economic collaboration between cultural enclaves and the outside world.

\section{References}

Adams, John. (1788). A Defense of the Constitutions of Government of the United States of America, Volume 3 (London: 1788), p.291.

Appell, G.N. (1977). 'The Plight of Indigenous Peoples: Issues and Dilemmas.' Survival International Review.

Appelberg K., Romanov K., Heikkilä K., Honkasalo M.L. \& Koskenvuo M. (1996). 'Interpersonal Conflict as a

Predictor of Disability: A Follow-up Study of 15348 Finnish Employees.' Journal of Psychosomatic Research, 40:157-167.

Balson, Steffan. (2015). 'The Other Story in Crimea: The Crimean Tatars.' IC Magazine, 34(18).

Calhoun, John C. (1851). A Disquisition on Government. St. Augustines Press (September 30, 2007).

Durkheim, Emile. (1893). The Division of Labor in Society. Palgrave Macmillan (1984)

Harris, Marvin. (1974). Cows, Pigs, Wars, and Witches: The Riddles of Culture. New York: Random House.

Hofstadter, Richard. (1948). The Marx of the Master Class. The American Political Tradition and the Men Who Made It. New York: A. A. Knopf.

Inglis, Judy. (1957). 'Cargo Cults: The Problem of Explanation.' Oceania, vol. xxvii no. 4

King, Richard ed. (2010). Art in Turmoil: The Chinese Cultural Revolution (1966-76). University of British Columbia Press.

Kinstler, Linda. (2014). 'The Crimean Tatars: A Primer.' New Republic $(3 / 2 / 2014)$ 
Kroeber, Theodora. (1964). Ishi: The Last of His Tribe. Berkeley, California Parnassus.

Lacy, K., \& Ford, Jr. (1994). 'Inventing the Concurrent Majority: Madison, Calhoun, and the Problem of Majoritarianism in American Political Thought.' The Journal of Southern History, 60(1), 19-58.

Lee, Hong Yong. (1978). The Politics of the Chinese Cultural Revolution. Berkeley: University of California Press.

Loomis, Ormund H. (1983). Cultural Conservation: The Protection of Cultural Heritage in the United States. Washington: Library of Congress.

Maybury-Lewis, David. (1977). 'Societies on The Brink.' Harvard Magazine, 1(2), 56-61.

Merton, Robert K. (1957). Social Theory and Social Structure. Revised edition. Glencoe, IL: Free Press.

Mill, John Stuart. (1859). On Liberty. Create Space Independent Publishing Platform..

Napoleon, Harold. (1996). Yuuyaraq: The Way of the Human Being. Alaska Native Knowledge Network.

Salzman, Michael. (2001). 'Cultural Trauma and Recovery: Perspectives From Terror Management Theory.' Trauma, Violence and Abuse, 2(2): 172-91.

Shevel, Oxana. (2014). 'To Strengthen Claims in Crimea Russia and Ukraine Woo Crimean Tatars.' Washington Post(3/25/2014).

Walle, Alf. (2004). The Path of Handsome Lake: Model of Recovery for Native People. Greenwich, Connecticut: IAP.

Wallace, Anthony. (1970). The Death and Rebirth of the Seneca: the History and Culture of the Great Iroquois Nation. New York: Alfred A. Knopf.

Worsley, Peter. (1957). The Trumpet Shall Sound: A Study of Cargo Cults in Melanesia. London: MacGibbon \& Kee. 
